A N N A L E S

UNIVERSITATIS MARIAE CURIE-SKŁODOWSKA

LUBLIN - POLONIA

VOL. LXVI, 1

SECTIO G

2019

Uniwersytet im. Adama Mickiewicza w Poznaniu

MARIA ZMIERCZAK

mariaz@amu.edu.pl

ORCID: 0000-0003-1116-3561

\title{
Demokracja a liberalizm - uwagi z perspektywy XXI w.
}

Democracy and Liberalism - Some Remarks in the Point of View of the $21^{\text {st }}$ Century

\section{LIBERALIZM EKONOMICZNY A LIBERALIZM POLITYCZNY}

W podręczniku do historii doktryn polityczno-prawnych spotykamy termin „demoliberalizm”. Samo słowo sugeruje, że jest to jakieś połączenie liberalizmu z demokracją, choć bardziej trafne byłoby użycie określenia „liberalizm pogodzony z demokracją". Wydawało się, że syntezą liberalnej zasady wolności i demokracji pojmowanej jako sprawowanie władzy przez większość jest idea państwa prawnego rozwijająca się od końca XVIII w. Termin „demokracja liberalna” był całkiem niedawno w powszechnym użyciu. Dziś coraz częściej mówi się o demokracji suwerennej, narodowej, a terminy „liberał” czy „liberalizm” nabrały w języku polityki pejoratywnego zabarwienia. Mówi się o „zgniłym liberalizmie” czy „lewackim liberalizmie”. Powstaje zatem pytanie: Jaką treść zawiera dziś termin „liberalizm”? Ostatnio autor jednego z artykułów napisał: „Dlaczego nikt nie płacze po liberalizmie? Przeciwnie: wszyscy wieszają na nim psy. Jego naturalni sojusznicy wolą dziś postawy autorytarne i silne państwa narodowe"2.

Wydaje się, że są dwie przyczyny takiej negatywnej postawy wobec liberalizmu. Pierwszą z nich jest utożsamienie liberalizmu z modelem gospodarki wolnorynkowej. Jest faktem, że w swoich początkach liberalizm był nurtem silnej opozycji wobec gospodarki opartej na królewskich monopolach, na koncesjach;

1 Zob. K. Chojnicka, H. Olszewski, Historia doktryn politycznych i prawnych. Podręcznik akademicki, Poznań 2004, s. 217.

2 J. Dymek, Wesele i kilka pogrzebów, „Tygodnik Powszechny”, 11.03.2018, s. 60. Jest to obszerne omówienie książki Edwarda Luce pt. The Retreat of Western Liberalism (New York 2017). 
przecież rewolucja amerykańska bezpośrednio wybuchła z powodu ograniczeń handlowych narzucanych przez metropolię. Widać to w dziełach Adama Smitha ${ }^{3}$ czy Alexisa de Tocqueville'a ${ }^{4}$. Jednakże najwybitniejsi myśliciele liberalni, jak Benjamin Constant czy Karl Rajmund Popper, dalecy byli od uznania, że wolność gospodarcza musi być nieograniczona. Co więcej, klasycy liberalizmu stosunkowo niewiele zajmowali się wolnością w zakresie gospodarki, bardziej interesowały ich prawa człowieka, równość wobec prawa, wolność słowa, sumienia, wyznania. Wystarczy nawet pobieżna lektura podręczników akademickich, żeby się przekonać, że John Stuart Mill zdefiniował prawo do wolności jednostki, które obejmuje ,całą tę część życia i postępowania człowieka, które wpływa tylko na niego samego lub jeśli wpływa na innych, to tylko dzięki swobodnemu i dobrowolnemu przyzwoleniu i współudziałowi”, a zaliczył do tej sfery wolność sumienia, myśli i uczucia, opinii i osądu, „układania planu naszego życia pod warunkiem ponoszenia konsekwencji, bez żadnej przeszkody ze strony naszych bliźnich, dopóki nasze czyny im nie szkodzą, choćby nawet uważali nasze postępowanie za głupie, przewrotne lub niesłuszne", wreszcie jako swobodę zrzeszania się „,w każdym celu nieprzynoszącym szkody innym"5. Liberalne zasady ekonomii i debata liberałów w sprawie interwencjonizmu państwa w gospodarkę ewoluowały, począwszy od końca XIX w., aż do końca XX w., ustępując pewnej syntezie, którą zwykło się nazywać liberalizmem społecznym czy socjalnym, którego przedstawicielami byli Leonard Trelawney Hobhouse, John Maynard Keynes czy rzecznicy doktryny społecznej gospodarki rynkowej. Jeszcze w latach 70. XX w. liberałowie niemieccy ogłosili słynny program. Pozwolił on im na współpracę z socjaldemokratami. Znalazły się w nim tezy o tym, że nastąpiła nowa faza rozwoju liberalizmu i demokratyzacji, wywodząca się ,,z rozwiniętego pojęcia »wolności«, które otwiera przed nowożytnym liberalizmem nowe, polityczne horyzonty liberalizmu nie tylko demokratycznego, ale i społecznego" - nie

3 Zob. A. Smith, Badania nad natura i przyczynami bogactwa narodów, t. 1, Warszawa 2007, s. 140-169. Autor wskazuje tu na „Nierówności, jakie powodują przepisy istniejące w Europie”, a mowa jest przede wszystkim o regulacjach cechowych i handlowych. Nawiasem mówiąc, po lekturze dzieła zgadzam się z tezą, że „Gdyby Adam Smith słyszał, iż powołują się na niego ekonomiści, którzy mówienie o społeczeństwie czy sprawiedliwości uważają za demagogię, spuściłby im publicystyczne manto”, którą Marek Beylin zawarł w artykule Zysk zaciemnia świadomość („Gazeta Wyborcza", 31.10.-2.11.2014).

4 De Tocqueville w pracy Dawny ustrój i rewolucja (Warszawa 1970, s. 91) opisuje m.in. rozporządzenia dawnej rady królewskiej: „Istnieją rozporządzenia rady zakazujące pewnych upraw na ziemiach uznanych przez tę radę za nieodpowiednie po temu. W jednym z rozporządzeń rada nakazuje powyrywać winorośle zasadzone jej zdaniem na złej ziemi, tak dalece rząd wyszedł już $\mathrm{z}$ roli panującego, a wszedł w rolę nadzorcy".

5 J.S. Mill, O wolności, Warszawa 1959, s. 132-134. Podręcznikiem akademickim, w którym myśl Milla została omówiona najobszerniej, jest niewątpliwie Lecha Dubela Historia doktryn politycznych i prawnych do schytku XX wieku (Warszawa 2009, s. 604-337). Zob. także: A.W. Czarnota, John Stuart Mill. Studium z dziejów liberalizmu politycznego, Warszawa-Poznań 1986, passim. 
chodzi już o wolność tylko wyizolowanej jednostki, lecz jednostki żyjącej w społeczeństwie; liberalizm społeczny „opowiada się za uzupełnieniem dotychczasowych liberalnych praw wolnościowych i praw ludzkich przez społeczne prawa do uczestniczenia i współdecydowania, i to nie tylko w zgodnej z konstytucją organizacji państwa, ale także w odnoszącej się do podziału pracy organizacji społeczeństwa"'.

Utożsamianie liberalizmu wyłącznie z nieograniczonym wolnym rynkiem, nieograniczoną swobodą własności i całkowitą swobodą umów jest więc co najmniej nieporozumieniem. Poniekąd zresztą była to konsekwencja coraz dalszego czy głębszego rozumienia „wolności jednostki”, bo przecież stawało się jasne, że swoboda umów, jak zauważył Hobhouse, przestaje istnieć, jeżeli jedna ze stron zawiera umowę pod groźbą głodu? ${ }^{7}$ Prawdziwa jest teza, że przez cały XX w. toczyła się debata i polemika w tej materii; polemika, którą symbolizowały dwie postaci, mianowicie John Maynard Keynes i Friedrich August von Hayek, co nader wyraziście przedstawił Nicholas Wapshott ${ }^{8}$.

Utożsamienie wolności z gospodarką wolnorynkową zostało dodatkowo wzmocnione - przez twórców i przede wszystkim ekonomistów związanych z Murrayem Rothbartem - libertarianizmem. Libertarianie uważali, że demokracja zniszczyła wolność oraz jednostkę głównie w dziedzinie wolności ekonomicznej, ale także mnożąc zakazy i konstruując coraz to nowe przestępstwa, owe victimless crimes, krępując jednostkę niemal w każdej dziedzinie, wprowadzając zakaz np. pornografii czy karząc prostytucję. Uznając, że wszystko, co nie szkodzi bezpośrednio drugiemu, nie powinno być zakazywane, libertarianie uważali za stosowne bronić jednostki przed jakimikolwiek ograniczeniami. Otóż wydaje się, że nawet Mill zgodziłby się współcześnie na zakaz palenia papierosów w miejscach publicznych czy zakaz ogrzewania domów przez spalanie śmieci, ponieważ dziś nasza wiedza nie pozostawia wątpliwości, że szkodzi to otoczeniu i innym ludziom. Niemniej libertariańska wizja wolności spowodowała niechęć do liberalizmu społecznego, a przez utożsamienie wolności z jak najdalej idącą samowolą doprowadziła - jak się zdaje - do nazywania liberałów anarchistami czy nawet do utożsamienia ich z libertynami. Najbardziej jaskrawym przykładem sprowadzania liberalizmu do nieokiełznanej wolności gospodarczej może być książka Hansa-Hermanna Hoppego, który w swoim dziele Demokracja - bóg, który zawiód oskarża demokrację o to, że okrada każdego człowieka, a poza tym snuje wyliczenia, w myśl których monarchie okradały poddanych mniej niż współcze-

6 Zob. Flach, Maihofer, Scheel. Fryburskie tezy liberałów, [w:] B. Sobolewska, M. Sobolewski, Myśl polityczna XIX i XX w. Liberalizm, Warszawa 1978, s. 592-597, cytaty ze s. 594.

7 Zob. M. Zmierczak, Leonard Trelawney Hobhouse - zapomniany prekursor liberalizmu społecznego, „Gdańskie Studia Prawnicze” 2009, nr 1, s. 448.

8 N. Wapshott, Keynes kontra Hayek. Spór, który zdefiniowat wspótczesna ekonomię, Warszawa 2013. 
sne państwo; wreszcie proponuje, by pozbyć się państwa i ogłosić suwerenność jednostki ${ }^{9}$. Autor nie ukrywa, że liberalizm demokratyczny zniszczył wolność. Niemal jak manifest brzmią jego słowa:

Z powodu podstawowego błędu swojej doktryny dotyczącego moralnego statusu rządu, liberalizm przyczynił się do zniszczenia wszystkiego, co pierwotnie zamierzał zachować i chronić: wolności i własności. Gdy przyjęto błędną zasadę rządu, ostateczne zwycięstwo socjalizmu nad liberalizmem było już tylko kwestią czasu. Obecny „koniec historii”, polegający na światowej dominacji forsowanej przez USA socjaldemokracji, to rezultat dwóch wieków liberalnych nieporozumień. Liberalizm w dzisiejszej swojej postaci nie ma przyszłości. Przyszłością takiego liberalizmu jest socjaldemokracja. Ta przyszłość już nadeszła (i wiemy, że nie o taką przyszłość chodzi) ${ }^{10}$.

Jednakże takie skojarzenie liberalizmu i ograniczenie go do nieskrępowanej działalności gospodarczej musiało wywołać krytykę liberalizmu, który współcześnie ma inne oblicze. $\mathrm{O}$ ile ortodoksyjni zwolennicy wolnego rynku zarazem krytykowali demokrację, uznając, że prawa ekonomii są niezmienne, o tyle liberalni demokraci rozszerzali pojęcie wolności np. na „wolność” od głodu, wolność od nędzy i niedostatku. W tym kontekście wolność - pojmowana przede wszystkim jako wolność słowa, poglądów, wyboru stylu życia - znajdowała się na drugim planie. Uważam, że ważniejszą rolę odgrywało w liberalizmie to, co było elementem politycznym, a nie ekonomicznym, nawet jeśli w początkach liberalizmu te elementy współgrały. Dla liberalizmu politycznego zaś najważniejsza była wolność jednostki w warunkach demokracji i powszechnego prawa wyborczego.

\section{STOSUNEK LIBERAŁÓW DO DEMOKRACJI - OBAWA PRZED DEMOKRACJĄ ANTYLIBERALNĄ}

Liberałowie zawsze mieli problem z demokracją i pojęciem suwerenności narodu. Nawet jeśli walczyli o obniżenie czy eliminację cenzusów majątkowych, nawet jeśli walczyli o prawa wyborcze dla kobiet, to zawsze zdawali sobie sprawę z tego, iż masy mogą się mylić; podkreślali też wagę debat parlamentarnych, starali się zapewnić równowagę racji i starannego prawodawstwa - miały temu służyć np. dwie izby parlamentu czy specjalne biura legislacyjne. Na ogół byli również przeciwni rozstrzyganiu problemów drogą referendów. Naturalną cechą liberalizmu była zatem troska o zachowanie wolności jednostki. To z czasem nakazywało im rozszerzyć prawo jednostki na prawa socjalne, w tym na prawo do nauki oraz na prawo do podstawowych dóbr niezbędnych do życia.

Fakt, że liberalizm jest obecnie kojarzony niemal wyłącznie z niekontrolowaną gospodarką, spowodował, że demokracja liberalna stała się podejrzana;

9 H.-H. Hoppe, Demokracja - bóg, który zawiódl, Warszawa 2006, passim (zwłaszcza s. 303-304).

10 Ibidem, s. 305. 
większą wagę przywiązuje się do demokracji pojmowanej jako wola większości czy wola narodu, w której decyzja tejże większości może dotyczyć wszystkiego. Jedynie demokracja liberalna wskazuje bardzo wyraźnie na to, że „wola większości" nie może być niczym nieograniczona. I tutaj widać wyraźnie granice między liberałami a demokratami, dla których wola większości, dobro narodu czy państwa zawsze może i musi przeważyć nad prawami jednostki. Tymczasem większość liberałów - poczynając od samego Milla, autora pracy Utylitaryzm - nie przyjmowała Benthamowskiego równania, w myśl którego można dokonać prostego rachunku przyjemności i przykrości wszystkich jednostek, a rząd powinien się kierować wynikiem tego rachunku. Klasyczni liberałowie uważali, że pewne wolności jednostki nie mogą być naruszane, choćby było to z korzyścią dla większości. Możemy sobie wyobrazić, że w imię racjonalnego i równomiernego rozwoju gospodarczego zostanie wydana ustawa regulująca np. rozmieszczenie lekarzy czy nauczycieli angielskiego w proporcji do ludności równomiernie w całym kraju, dając przy tym organom władzy prawo do kierowania ich do określonych miejsc pracy. Nakazy pracy istniały przecież w PRL. Każdy liberał powie, że jest to ograniczenie wolności jednostki i żadna władza demokratyczna nie ma prawa do takich posunięć, a jednym z najbardziej znanych haseł liberalnych jest hasło „ułożenia planu własnego życia”. Z drugiej strony granice wolności indywidualnej jednak się zmieniały i będą się zmieniać m.in. dlatego, że pojęcie tego, co szkodzi bliźniemu, zmienia się wskutek naszej wiedzy. Prosty przykład: w XIX w. zapewne nikomu nie przyszłoby do głowy zakazać palenia papierosów w miejscach publicznych. Tymczasem dziś postęp medycyny i nauki nie pozostawia wątpliwości, że rak płuc ma ścisły związek nie tylko z paleniem papierosów, ale i wdychaniem zanieczyszczonego powietrza. Jest więc oczywiste, że nikt nie ma prawa narażać innych na wdychanie dymu, czy to paląc w ich obecności papierosy, czy spalając szkodliwe śmieci w domowych piecach. Podobnie rozwój psychologii wskazuje na negatywne skutki oglądania przez dzieci zabijania zwierząt czy oglądania bez ograniczeń drastycznych treści w telewizji, a zatem społeczeństwo może podjąć próby zakazania takiego stylu wychowania. Myślę, że i Mill, i Popper zgodziliby się $\mathrm{z}$ tym rozumowaniem.

Nawet jednak przyjmując założenie, iż granice wolności jednostki mogą się zmieniać, liberałowie nie są gotowi zaaprobować idei, iż wola większości może o nich decydować zawsze i bez żadnych racjonalnych powodów. Dlatego też z nieufnością się odnosili i nadal się odnoszą do idei Jana Jakuba Rousseau, iż „suwerenność ludu jest niepodzielna, nieograniczona i niezbywalna” oraz że jednostka nie może mieć jakichkolwiek praw, które mogłaby powoływać przeciw woli powszechnej, czyli woli ludu. Bodaj najbardziej dosadną polemikę z Rousseau przeprowadził Constant, odwołując się do tez Umowy społecznej w następujących słowach: 
Suwerenność istnieje tylko w sensie ograniczonym i względnym. [...] Zgoda większości nie zawsze wystarcza do uznania jej aktów za legalne, są rzeczy, których nic nie jest w stanie zakwestionować; jeżeli jakakolwiek władza popełni podobne akty, to nie jest ważne, z jakich źródeł ona wypływa i czy nazywa się ona jednostką czy narodem; gdyby nawet była całym narodem, zmniejszonym o obywatela uciskanego - nie byłaby bardziej legalna ${ }^{11}$.

Różnica w pojmowaniu wolności jednostki i wolności narodu jest jedną z najważniejszych różnic między demokratami a liberałami, na co już dawno zwrócił uwagę Isaiah Berlin ${ }^{12}$. Podkreślił też to, że upowszechniło się pojmowanie narodu jako bytu ponad jednostkami, a pojęcie wolności narodu było wykorzystywane do budowy dyktatur legitymizowanych jako demokratyczna wola większości.

Liberałowie współcześni pamiętają jednak przede wszystkim, że o końcu liberalizmu - najczęściej również utożsamianego z gospodarką - nader chętnie mówił Benito Mussolini. Przypomnijmy, że w Doktrynie faszyzmu bardzo wyraźnie powiedział, iż faszyzm jest przeciwny „klasycznemu liberalizmowi, który powstał z konieczności przeciwstawienia się absolutyzmowi i wyczerpał swe zadanie historyczne $\mathrm{z}$ chwilą, gdy państwo zmieniło się w świadomość i wolę zbiorową"13. Nie pozostawiał on złudzeń co do wolności jednostki, stwierdzając:

Jesteśmy pierwsi, którzy w obliczu demoliberalnego indywidualizmu stwierdzili, że jednostka istnieje o tyle tylko, o ile jest w państwie i podporządkowana koniecznością państwa, i że w miarę, jak społeczność przybiera coraz bardziej złożone formy, wolność jednostki coraz bardziej się kurczy ${ }^{14}$.

W publicystyce i przemówieniach Adolfa Hitlera krytyka „liberalno-żydowskiego światopoglądu" i żądanie zastąpienia liberalnej demokracji prawdziwą germańską demokracją, która miała polegać na powierzeniu wodzowi pełni władzy, była istotnym elementem retoryki ${ }^{15}$. Doświadczenie historyczne też poucza, że demokracja antyliberalna jest możliwa, bo przecież i Hitler, i Mussolini doszli do władzy z antyliberalną retoryką, ale w oparciu o demokratyczne wybory i legalną działalność ich partii.

Tym, co łączy liberałów dziś, jest obawa przed ograniczeniem wolności jednostki przez wolę absolutnej większości wyrażaną w demokratycznych procedurach $-\mathrm{w}$ wyborach lub referendum. Obawy te potwierdziło doświadczenie historyczne (przede wszystkim w XX w.), bo przecież niejedna demokracja bez

11 Cyt. za: W. Szyszkowski, Beniamin Constant. Doktryna polityczno-prawna na tle epoki, Warszawa 1984, s.72.

12 Zob. I. Berlin, Dwie koncepcje wolności, [w:] idem, Dwie koncepcje wolności i inne eseje, wyb. i oprac. J. Jedlicki, Warszawa 1991, s. 108 i n. (zwłaszcza s. 176-183).

13 B. Mussolini, Doktryna faszyzmu, cyt. za: Wybór tekstów źródlowych z historii doktryn polityczno-prawnych, wyb. i oprac. J. Justyński, Torun 2004, s. 315.

14 Ibidem, s. 316.

15 Zob. M. Zmierczak, Krytyka demokracji w ideologii Adolfa Hitlera, „Studia nad Faszyzmem i Zbrodniami Hitlerowskimi” 2010, t. 32, s. 75-92. 
wojny domowej przekształciła się w dyktaturę, ale i niejedna demokratyczna idea była stale przywoływana przez tych, którzy powoływali się na wolność narodu, pomijając wolność jednostki. Aktualnie jesteśmy świadkami procesu, w którym demokracja zostaje sprowadzona do uzyskania poparcia większości, prawo jest wyrazem woli większości bez zastrzeżenia, iż - jak pisał Mill - „demokracja to rządy większości, ale z poszanowaniem praw mniejszości”.

Wydawało się, że mariaż liberalizmu i demokracji, występujący w podręcznikach pod nazwą demoliberalizmu, jest syntezą trwałą. Wiemy, że demokracja nieliberalna była i jest możliwa.

W demokracji pojawił się m.in. taki element, jak nieograniczona wola większości, której jednostka winna się całkowicie podporząakować. Doświadczenie pouczające, że demokracja może być groźna dla jednostki, sięga ponad dwóch tysięcy lat. Sokrates, skazany na śmierć decyzją większości za głoszone poglądy, jest tu klasycznym przykładem.

\section{PERSPEKTYWY: LIBERALIZM JAKO OBRONA JEDNOSTKI PRZECIW AUTORYTARNEJ I TOTALITARNEJ WŁADZY}

Sam termin „liberalizm” - jak starałam się wykazać - niesłusznie jest kojarzony wyłącznie z liberalizmem ekonomicznym, natomiast nadal jest jedynym narzędziem do obrony przed autorytaryzmami i totalitaryzmami wszelkiej proweniencji. Trafnie zauważono, że po zrealizowaniu większości postulatów liberalnych - dotyczących równości wobec prawa, wolności słowa, wolności jednostki ograniczonej przez taką samą wolność innych jednostek, w połączeniu z dążeniem do konstytucyjnego ujęcia tychże wolności - liberałowie nie tworzyli znaczących partii politycznych, a jeśli takowe były, to na pierwszym planie stawiały postulaty ekonomiczne, podatkowe i dotyczące własności prywatnej, jak miało to miejsce w przypadku thatcheryzmu czy reaganizmu. Ale też historia poucza nas i wskazuje, że liberalizm wracał i rozwijał się jako doktryna czy ideologia polityczna wszędzie i zawsze tam, gdzie wolność jednostki była zagrożona.

Można by powiedzieć zasadnie, iż po II wojnie światowej większość postulatów liberałów została zrealizowana, prawa człowieka stały się oczywiste $\mathrm{w}$ demokracjach zachodnich. Zainteresowanie liberalizmem trwało natomiast w państwach komunistycznych, wystarczy popatrzeć na publikacje podziemnych wydawnictw np. w PRL. Liberałowie zawsze byli związani z ideą wolności słowa i poglądów, a na pierwszym planie znajdowało się pojęcie wolności jednostki.

Liberalizm jest formułą przeciwstawiania się dyktaturze, czego wyrazistym przykładem był liberalizm w II Cesarstwie Francuskim, kiedy to stanowił płaszczyznę oporu przeciw autorytarnym rządom Napoleona III $^{16}$, co znacznie

16 Zob. eadem, Ideologia liberalna w II Cesarstwie Francuskim, Poznań 1978. 
przyczyniło się do liberalizacji Cesarstwa po 1860 r. Liberalizm był płaszczyzną walki z faszyzmem w dwudziestoleciu międzywojennym oraz podstawą ładu europejskiego po II wojnie światowej, szczególnie w postaci europejskiej Deklaracji Praw Człowieka.

Liberalizm przestał być samodzielną siłą polityczną, ponieważ większość jego postulatów została przyswojona przez niemal wszystkie odłamy i ugrupowania polityczne, poza radykalnymi nacjonalistami czy populistami. Czy idea poszanowania wolności indywidualnej znowu stanie się ważna? Wydaje się, że tylko i dopiero wówczas, gdy wolność jednostki w każdym aspekcie zostanie naruszona. Jest wiele prawdy w twierdzeniu, że „liberalizm to punkt zbiorczy opozycji”.

Historyk idei ma skłonność do pewnego schematyzowania. Jestem przekonana, że należałoby więcej miejsca poświęcić na analizę i przeobrażenia treści przypisywanych liberalizmowi, pokazanie ewolucji poglądów liberałów (zwłaszcza w dziedzinie ekonomii), porównanie i wskazanie, że jednym z istotnych elementów współczesnego liberalizmu jest poszanowanie wolności jednostki, poszanowanie procedur i konstytucji, a także idea państwa prawnego.

Doświadczenie historyczne wskazuje, że liberalizm zaczyna być niezwykle ważny przede wszystkim w sytuacji, gdy władza przestaje zważać na prawa jednostki. Wówczas, jak już dawno zauważono, staje się on ,punktem zbornym opozycji”. Miało to miejsce w momencie kryzysu monarchii absolutnej czy to w Anglii, czy w osiemnastowiecznej Francji; bardzo wyraźnie zaznaczyło się to w II Cesarstwie Francuskim; wyraziste było też na całym świecie po II wojnie światowej, kiedy w opozycji do minionego czy wciąż istniejącego totalitaryzmu zaczęto mówić o prawach i wolnościach, a Europa przyjęła Deklarację Praw Człowieka. To wreszcie spowodowało popularność liberalizmu w walce przeciw reżimom komunistycznym, o czym zaświadcza książka Jerzego Szackiego Liberalizm po komunizmie ${ }^{17}$. Chodzi tu głównie o jednostkę, jej prawa oraz o ustrój, który jej te prawa zagwarantuje. Jeżeli nawet słowo „liberalizm” jest dziś wyklinane czy wyśmiewane, to mam wrażenie, że dotycząca liberalizmu uwaga Pierre'a Guirala niezmiennie pozostaje trafna: ,,...] liberalizm krystalizuje opozycje, jest ich naturalnym sprzymierzeńcem, ich punktem zbornym, opozycjoni-

17 J. Szacki, Liberalizm po komunizmie, Kraków 1994, s. 15. Autor trafnie zauważa: „Jeżeli dokonujące się w Europie Wschodniej zmiany obejmują jednocześnie odnowę i restaurację, to liberałowie należą z pewnością do tych polityków, dla których sprawą podstawową jest dzisiaj odnowa. Inaczej mówiąc, to właśnie liberalizm daje dzisiaj najbardziej spójny projekt nowego ładu polityczno-społeczno-gospodarczego, podczas gdy rzecznicy innych orientacji często poprzestają na krytykowaniu tego projektu w imię owych, odwołujących się do sentymentów i resentymentów, schematów oraz do jego »uzupełniania« i »korygowania«; kiedy zaś uzyskują wpływ na bieg wydarzeń, robią mniej więcej to samo, co liberałowie. Trzeba też pamiętać, iż pewne składniki liberalnego credo nie są w istocie kwestionowane przez nikogo [...]”. 
ści z prawa i z lewa przywołują jego zasady, wykorzystują jego metody, wspierają jego zwolenników”"18.

Zarazem doświadczenie historyczne pozwala wnioskować, że pogarda dla liberalizmu zwykle jest pierwszym elementem pogardy dla wolności i praw pojedynczego człowieka oraz początkiem ich ograniczania, co często kończy się po prostu dyktaturą.

\section{BIBLIOGRAFIA}

Berlin I., Dwie koncepcje wolności, [w:] idem, Dwie koncepcje wolności i inne eseje, wyb. i oprac. J. Jedlicki, Warszawa 1991.

Beylin M., Zysk zaciemnia świadomość, „Gazeta Wyborcza”, 31.10.-2.11.2014.

Chojnicka K., Olszewski H., Historia doktryn politycznych i prawnych. Podręcznik akademicki, Poznań 2004.

Czarnota A.W., John Stuart Mill. Studium z dziejów liberalizmu politycznego, Warszawa-Poznań 1986.

Dubel L., Historia doktryn politycznych i prawnych do schyłku XX wieku, Warszawa 2009.

Dymek J., Wesele i kilka pogrzebów, „Tygodnik Powszechny”, 11.03.2018.

Flach, Maihofer, Scheel. Fryburskie tezy liberałów, [w:] B. Sobolewska, M. Sobolewski, Myśl polityczna XIX i XX w. Liberalizm, Warszawa 1978.

Guiral P., Le libéralisme en France (1815-1870). Thèmes, succès et lacunes, [w:] idem, Tendances politiques dans la vie française depuis 1789, Paris 1960.

Hoppe H.-H., Demokracja - bóg, który zawiódt, Warszawa 2006.

Luce E., The Retreat of Western Liberalism, New York 2017.

Mill J.S., O wolności, Warszawa 1959.

Smith A., Badania nad natura i przyczynami bogactwa narodów, t. 1, Warszawa 2007.

Szacki J., Liberalizm po komunizmie, Kraków 1994.

Szyszkowski W., Beniamin Constant. Doktryna polityczno-prawna na tle epoki, Warszawa 1984.

Tocqueville A. de, Dawny ustrój i rewolucja, Warszawa 1970.

Wapshott N., Keynes kontra Hayek. Spór, który zdefiniowat wspótczesna ekonomię, Warszawa 2013.

Wybór tekstów źródłowych z historii doktryn polityczno-prawnych, wyb. i oprac. J. Justyński, Toruń 2004.

Zmierczak M., Ideologia liberalna w II Cesarstwie Francuskim, Poznań 1978.

Zmierczak M., Krytyka demokracji w ideologii Adolfa Hitlera, „Studia nad Faszyzmem i Zbrodniami Hitlerowskimi” 2010, t. 32.

Zmierczak M., Leonard Trelawney Hobhouse - zapomniany prekursor liberalizmu społecznego, „Gdańskie Studia Prawnicze” 2009, nr 1.

\section{SUMMARY}

Nowadays the term "liberalism" is more and more used in political debates together with pejorative adjectives like "rotten", "passed" and others. Instead of "liberal democracy" we hear about "sovereign democracy", "independent democracy" and of course "national democracy". Looking for the roots of such development, the author sees one of them in the identification of liberal

18 P. Guiral, Le libéralisme en France (1815-1870). Thèmes, succès et lacunes, [w:] idem, Tendances politiques dans la vie française depuis 1789, Paris 1960, s. 29. 
ideas with the liberal economy. Although the deepened studies show, that even the most prominent liberals never were so orthodox like the libertarians, among them especially Hans-Hermann Hoppe, for whom no liberty is possible without absolute freedom of property, commerce and production. The idea is false, taking into account the liberals like John Maynard Keynes, even John Stuart Mill or Leonard Trelawney Hobhouse. The second misunderstanding is in the notion of democracy. Nowadays the most popular idea is that democracy means simply the political majority. That is the point in which the liberals were always very cautious, beginning with Benjamin Constant, Alexis de Tocqueville and John Stuart Mill. The liberals accepted democracy, but - according to the famous words of Mill - defined as the rule of majority, but with respect of minorities. It is clear, that this role of liberalism is nowadays in retreat. Democracy is often meant and understood as the sovereignty of the people, according to the words of Jean-Jacques Rousseau "unlimited, unalienable and indivisible", and means freedom of nation and not freedom of individual. The historical experience shows that such "unlimited will of the people" was used as a veil for the most horrific political systems. But on the other hand, it is clear that under authoritarian regimes, liberalism, especially political liberalism, becomes the point of gathering of the opposition, as the examples of II French Empire, of fascist Italy, German III Reich, and communist regime confirm.

Keywords: rotten liberalism; economic liberalism; political liberalism; liberal democracy; sovereign democracy

\section{STRESZCZENIE}

Punktem wyjścia w niniejszym opracowaniu jest stwierdzenie faktu, że termin „liberalizm” nabiera pejoratywnego charakteru; w wypowiedziach polityków i publicystów pojawiają się określenia typu „zgniły” „upadły” czy „skompromitowany” liberalizm. Przyczyną tego zjawiska jest utożsamienie terminu „liberalizm” z nieograniczoną gospodarką wolnorynkową albo z absolutną, niemal anarchistyczną wolnością jednostki. To zjawisko nasiliło się szczególnie za sprawą szkoły chicagowskiej i libertarianizmu, czego najbardziej wymownym przykładem jest książka Demokra$c j a-b o ́ g$, który zawiódt. Druga przyczyna to niewątpliwie stosunek klasycznych liberałów do demokracji. Liberałowie walczyli wprawdzie o powszechne prawa wyborcze (także dla kobiet), ale ich naczelnym zadaniem i ideałem było postawienie granic temu, co Jan Jakub Rousseau określił jako „nieograniczoną, suwerenną i niepozbywalną władzą ludu (narodu)”. Stąd określenie „demokracja liberalna" zawierało konkretną treść, taką jak prawa jednostki, rządy prawa, podział władzy. Jesteśmy aktualnie świadkami wzrostu popularności ideału Rousseau, mówi się przecież o „suwerennej demokracji”, woli narodu. To każe jednak pamiętać, że właśnie rządy autorytarne i totalitarne posługiwały się taką retoryką, mówiąc o demokracji jako o wyrazie woli narodu i nie przewidując żadnych dla tej woli ograniczeń. Czy to oznacza kres idei liberalnych? Historia poucza nas, że liberalizm stawał się ważną ideologią zawsze w momentach kryzysowych, jak np. w II Cesarstwie Francuskim, jak również po upadku III Rzeszy, dyktatury Francisco Franco i komunizmu. Można sądzić, że nie tyle liberalizm jako teoria ekonomiczna, ile liberalizm jako ograniczenie władzy absolutnej - nawet jeśli władza ta pochodzi z demokratycznych wyborów - będzie nadal spełniać tę funkcję.

Słowa kluczowe: zgniły liberalizm; liberalizm ekonomiczny; liberalizm polityczny; demokracja liberalna; demokracja suwerenna 